Correspondence

Svetlana N. Dedysh

dedysh@mail.ru

\section{Methylovirgula ligni gen. nov., sp. nov., an obligately acidophilic, facultatively methylotrophic bacterium with a highly divergent $m x a F$ gene}

\author{
Alexey V. Vorob'ev, ${ }^{1}$ Wietse de Boer, ${ }^{2}$ Larissa B. Folman, ${ }^{2}$ \\ Paul L. E. Bodelier, ${ }^{3}$ Nina V. Doronina, ${ }^{4}$ Natalia E. Suzina, ${ }^{4}$ \\ Yuri A. Trotsenko ${ }^{4}$ and Svetlana N. Dedysh ${ }^{1}$
}
${ }^{1}$ S. N. Winogradsky Institute of Microbiology, Russian Academy of Sciences, Moscow 117312 , Russia
${ }^{2}$ Netherlands Institute of Ecology, Centre for Terrestrial Ecology, 6666 ZG Heteren, The Netherlands
${ }^{3}$ Netherlands Institute of Ecology, Centre for Limnology, 3631 AC Nieuwersluis, The Netherlands
${ }^{4}$ G. K. Skryabin Institute of Biochemistry and Physiology of Microorganisms, Russian Academy of Sciences, Pushchino, Moscow region, 142292, Russia

Two strains of Gram-negative, aerobic, non-pigmented, non-motile, rod-shaped bacteria were isolated from beechwood blocks during decay by the white-rot fungus Hypholoma fasciculare and were designated strains BW863 ${ }^{\top}$ and BW872. They are capable of methylotrophic growth and assimilate carbon via the ribulose-bisphosphate pathway. In addition to methanol, the novel isolates utilized ethanol, pyruvate and malate. Strains BW863 ${ }^{\top}$ and BW872 are obligately acidophilic, mesophilic organisms capable of growth at $\mathrm{pH}$ 3.1-6.5 (with an optimum at $\mathrm{pH}$ 4.55.0) and at $4-30{ }^{\circ} \mathrm{C}$. Phospholipid fatty acid profiles of these bacteria contain unusually large amounts (about $90 \%$ ) of $\mathrm{C}_{18: 1} \omega 7 c$, thereby resembling the profiles of Methylobacterium strains. The predominant quinone is $\mathrm{Q}-10$. The DNA G+C content of the novel isolates is 61.8$62.8 \mathrm{~mol} \%$. On the basis of $16 \mathrm{~S}$ rRNA gene sequence similarity, strains BW863 ${ }^{\top}$ and BW872 are most closely related to the acidophilic methanotroph Methylocapsa acidiphila $\mathrm{B}^{\top}{ }^{\top}$ (96.5$97 \%$ ). Comparative sequence analysis of $m x a F$, the gene encoding the large subunit of methanol dehydrogenase, placed the MxaF sequences of the two novel strains in a cluster that is distinct from all previously described MxaF sequences of cultivated methylotrophs. The identity between the MxaF sequences of the acidophilic isolates and those from known alpha-, beta- and gammaproteobacterial methylotrophs was respectively 69-75, 61-63 and 64-67\%. The data therefore suggest that strains BW863 ${ }^{\top}$ and BW872 represent a novel genus and species of methylotrophic bacteria, for which the name Methylovirgula ligni gen. nov., sp. nov. is proposed. Strain BW863 ${ }^{\top}\left(=\mathrm{DSM} 19998^{\top}=\mathrm{NCIMB} 14408^{\top}\right)$ is the type strain of Methylovirgula ligni.
Abbreviations: ICM, intracytoplasmic membrane; PLFA, phospholipid fatty acid; PMS, phenazine methosulfate; RuBisCO, ribulose-1,5-bisphosphate carboxylase/oxygenase; RuBP, ribulose bisphosphate; SIP, stable-isotope probing.

The GenBank/EMBL/DDBJ accession numbers for the 16S rRNA gene sequences and partial mxaF gene sequences of strains BW863 ${ }^{\mathrm{T}}$ and BW872 are respectively FM252034 and FM252035 (16S rRNA gene) and FM252036 and FM252037 ( $m \times a F$ ), and those for the partial nifH and $\mathrm{CbbL}$ gene sequences of strain $B W 863^{\top}$ are respectively FM252038 and FM252039.

EMs contrasting the morphology of strain $\mathrm{BW} 63^{\top}$ and Methylocapsa acidiphila $B 2^{\top}$, a graph showing the growth response of strain BW863 ${ }^{\top}$ to $\mathrm{pH}$ and an extended 16S rRNA gene-sequence based neighbourjoining tree are available as supplementary material with the online version of this paper.
Aerobic methylotrophic bacteria are a specialized group of micro-organisms that can utilize reduced carbon substrates with no carbon-carbon bonds as a sole source of carbon and energy (Lidstrom, 2006). Methanol is the major substrate for non-methanotrophic methylotrophs that inhabit terrestrial environments, where it is produced during the decomposition of fallen woody materials and plant debris (Ander \& Eriksson, 1984; Warneke et al., 1999). Most terrestrial environments in the Northern hemisphere, such as forest soils and wetlands of the temperate and boreal zones, are acidic ( $\mathrm{pH} 3-5$ ). Identification of active methylotroph populations in an acidic forest soil by stable-isotope probing (SIP) with ${ }^{13} \mathrm{C}$ methanol suggested that a novel group of as-yet-uncultiv- 
ated methylotrophs within the Alphaproteobacteria was a key player in this process (Radajewski et al., 2000, 2002). In this paper, we describe two representatives of this previously uncultivated group of bacteria and propose a novel genus and species, Methylovirgula ligni gen. nov., sp. nov., for these obligately acidophilic methylotrophs.

Two strains of Gram-negative bacteria were isolated from beechwood blocks incubated on the surface of an acidic ( $\mathrm{pH}$ 3.3-3.6) forest soil during decay by the white-rot fungus Hypholoma fasciculare (Folman et al., 2008), and were designated strains $\mathrm{BW} 863^{\mathrm{T}}$ and BW872. The media used for isolation of strains $\mathrm{BW} 863^{\mathrm{T}}$ and BW872 were water yeast agar of $\mathrm{pH} 5$ (medium W5) and 1/10-strength trypticase soy broth agar of pH 5 (medium T5), respectively. Medium W5 had the following composition (per litre of demineralized water): $\mathrm{NaCl}, 1 \mathrm{~g}$; yeast extract (Difco Technical grade), $0.1 \mathrm{~g} ; 2$-[ $\mathrm{N}$-morpholino]ethanesulfonic acid (MES; Sigma) as a buffering compound, $1.95 \mathrm{~g}$; and agar (Baker's Agar Technical), 20 g. Medium T5 contained (per litre): $\mathrm{NaCl}, 1 \mathrm{~g}$; trypticase soy broth (Oxoid), $3 \mathrm{~g}$; MES, $1.95 \mathrm{~g}$; and agar, $20 \mathrm{~g}$. Details of the isolation procedure were published previously (Folman et al., 2008). Partial sequencing of the 16S rRNA genes from these novel isolates showed that they are affiliated with the Alphaproteobacteria and are most closely related (97\% sequence similarity) to the acidophilic, obligately methanotrophic bacterium Methylocapsa acidiphila $\mathrm{B}^{\mathrm{T}}{ }^{\mathrm{T}}$. This unexpected finding suggested that the isolates may be capable of $\mathrm{C}_{1}$ metabolism and that the media used to isolate these bacteria may not support their optimal growth. The latter became evident with further attempts to maintain strains BW863 ${ }^{\mathrm{T}}$ and BW872 on media W5 and T5, since only a trace of growth could be observed after 3-4 weeks of incubation. Replacement of W5 and T5 with slightly modified medium M2 (designated medium MM2), which is used routinely for cultivation of Methylocapsa acidiphila (Dedysh et al., 2002), resulted in good development of strains $B W 863^{\mathrm{T}}$ and BW872 when methanol was provided as a growth substrate. Thus, further maintenance and cultivation experiments with these bacteria were performed using medium MM2 of the following composition (per litre distilled water): $\mathrm{KH}_{2} \mathrm{PO}_{4}$, $100 \mathrm{mg} ; \quad\left(\mathrm{NH}_{4}\right)_{2} \mathrm{SO}_{4}, \quad 200 \mathrm{mg} ; \quad \mathrm{MgSO}_{4}, \quad 50 \mathrm{mg}$; $\mathrm{CaCl}_{2} \cdot 2 \mathrm{H}_{2} \mathrm{O}, 20 \mathrm{mg}$; yeast extract, $10 \mathrm{mg}$; methanol, $0.5 \%(\mathrm{v} / \mathrm{v}) ; \mathrm{pH} 4.8-5.2$. For growth in liquid media, $500 \mathrm{ml}$ screw-capped serum bottles were used with a headspace/liquid space ratio of $4: 1$. After inoculation, methanol was added aseptically to the cultures and the bottles were capped with silicone rubber septa to prevent loss of methanol by evaporation. Bottles were incubated on a rotary shaker (120 r.p.m.) at $24{ }^{\circ} \mathrm{C}$.

Morphological observations and cell-size measurements were made with a Zeiss Axioplan 2 microscope and Axiovision 4.2 software (Zeiss). For the preparation of ultrathin sections, cells of exponentially growing cultures were collected by centrifugation and pre-fixed with $1.5 \%$ (w/v) glutaraldehyde in $0.05 \mathrm{M}$ cacodylate buffer ( $\mathrm{pH} 7.2)$ for $1 \mathrm{~h}$ at $4{ }^{\circ} \mathrm{C}$ and then fixed in $1 \%(\mathrm{w} / \mathrm{v}) \mathrm{OsO}_{4}$ in the same buffer for $4 \mathrm{~h}$ at $20^{\circ} \mathrm{C}$. After dehydration in an ethanol series, samples were embedded in Epon 812 epoxy resin. Thin sections were cut on an LKB-2128 Ultrotome, stained with $3 \%(\mathrm{w} / \mathrm{v})$ uranyl acetate in $70 \%(\mathrm{v} / \mathrm{v})$ ethanol and then post-stained with lead citrate (Reynolds, 1963) at $20{ }^{\circ} \mathrm{C}$ for $4-5 \mathrm{~min}$. Specimen samples were examined with a JEM-100B transmission electron microscope at $80 \mathrm{kV}$ accelerating voltage.

Physiological tests were performed in liquid medium MM2 with methanol as the sole growth substrate. Growth of isolates was monitored by nephelometry at $600 \mathrm{~nm}$ for 3 weeks under a variety of growth conditions, including temperatures of $4-37{ }^{\circ} \mathrm{C}$, $\mathrm{pH} 2.9-8.0$ and $\mathrm{NaCl}$ concentrations of $0.01-2 \%(\mathrm{w} / \mathrm{v})$. Variations in $\mathrm{pH}$ were achieved by mixing $0.1 \mathrm{M}$ solutions of $\mathrm{H}_{2} \mathrm{SO}_{4}$ and $\mathrm{NaOH}$. The range of potential growth substrates was examined using $0.05 \%(\mathrm{w} /$ v) concentrations of the following carbon sources: formate, formamide, formaldehyde, methylamine, dimethylamine, trimethylamine, glucose, arabinose, xylose, lactose, maltose, rhamnose, raffinose, sucrose, sorbose, fructose, acetate, malate, oxalate, pyruvate, succinate, citrate, mannitol, myoinositol and ethanol. The ability to grow with methane as the sole growth substrate was tested with $10-20 \%(\mathrm{v} / \mathrm{v})$ methane in the headspace of experimental bottles. Nitrogen sources were tested by replacing $\left(\mathrm{NH}_{4}\right)_{2} \mathrm{SO}_{4}$ in MM2 with $0.05 \%(\mathrm{w} / \mathrm{v}) \mathrm{KNO}_{3}, \mathrm{NaNO}_{2}$, urea, glycine, alanine or yeast extract.

Cell biomass for cellular fatty acid and isoprenoid quinone analyses and for DNA extraction was obtained from batch cultures grown in liquid medium MM2 with methanol at $24{ }^{\circ} \mathrm{C}$ for 7 days. Isoprenoid quinones were extracted according to Collins (1985) and analysed using an LCQ Advantage Max tandem-type mass spectrometer and a Finnigan Mat 8430 ionization mass spectrometer. Fatty acid analysis was performed as described previously (Dedysh et al., 2007). Polar lipids were extracted from cell biomass with chloroform/methanol $(1: 2, \mathrm{v} / \mathrm{v})$ by stirring for $1 \mathrm{~h}$ in an ice bath, followed by centrifugation at $5000 \mathrm{~g}$ for $20 \mathrm{~min}$; during this time, the two phases were separated. The procedure of extraction was performed twice and the upper phases were collected and combined. Two millilitres of chloroform and $2 \mathrm{ml}$ distilled water were added to the supernatant and the resulting mixture was subjected to careful shaking for $15 \mathrm{~min}$ in an ice bath. The mixture was then centrifuged and, during this time, three phases were separated. The lower phase with polar lipids was withdrawn, evaporated at $30^{\circ} \mathrm{C}$ and dissolved in $200 \mu \mathrm{l}$ chloroform. Polar lipids were separated by two-dimensional TLC (Kieselgel 60, 10 $\times 10 \mathrm{~cm}$; Merck) using chloroform/methanol/7 $\mathrm{M}$ sodium hydroxide $(60: 30: 4$ by vol.) in the first direction followed by chloroform/methanol/acetic acid/ water $(85: 12.5: 12.5: 3$ by vol.) in the second direction. Plates were sprayed with various specific reagents for detection of different phospholipids (Kates, 1972). Phospholipid standards (Sigma) were used for identification of phospholipids during comparative analysis. 
The DNA base composition was determined by thermal denaturation using a Unicam SP1800 spectrophotometer at a heating rate of $0.5^{\circ} \mathrm{C} \mathrm{min}{ }^{-1}$. The $\mathrm{G}+\mathrm{C}$ content was calculated according to Owen et al. (1969). PCR-mediated amplification of the 16S rRNA gene was performed using primers $9 \mathrm{f}$ and $1492 \mathrm{r}$ and reaction conditions described by Weisburg et al. (1991). Partial fragments of the mxaF gene (encoding the large subunit of methanol dehydrogenase), the nifH gene (encoding dinitrogenase reductase) and the $c b b L$ gene [encoding the large subunit of form I ribulose1,5-bisphosphate carboxylase/oxygenase (RuBisCO)] were amplified using primers and reaction conditions described, respectively, by McDonald \& Murrell (1997), Dedysh et al. (2004b) and Spiridonova et al. (2004). The PCR-amplified gene fragments were purified using the Wizard PCR Preps DNA Purification System (Promega) and sequenced on an ABI Prism 377 DNA sequencer (PE Applied Biosystems). Phylogenetic analysis was carried out using the ARB program package (Ludwig et al., 2004).

Small $(0.5-1 \mathrm{~mm})$, opaque, light-cream, circular colonies with entire edges and a smooth surface developed on agar medium MM2 after incubation for 2 weeks at $24{ }^{\circ} \mathrm{C}$. Liquid cultures displayed white turbidity; a surface pellicle was not formed. Cells of strains BW863 ${ }^{\mathrm{T}}$ and BW872 were Gram-negative, non-motile, straight or slightly curved, thin rods, $0.3-0.65 \mu \mathrm{m}$ wide and $1.2-2.5 \mu \mathrm{m}$ long. They reproduced by binary fission and occurred singly or were arranged in rosettes and misshapen cell clusters (Fig. 1a). The formation of rosettes was most pronounced in old cultures (2 weeks or more). No capsule formation and no resting cell forms were observed. Overall, the cell morphology of the novel isolates was strikingly different from that of Methylocapsa acidiphila $\mathrm{B}^{\mathrm{T}}{ }^{\mathrm{T}}$ (Supplementary Fig. S1, available in IJSEM Online).

Thin sections were prepared from both plate and liquid cultures of strains BW863 ${ }^{\mathrm{T}}$ and BW872 (Fig. 1b-d). Cells grown on agar medium possessed 5-nm-thick pilus-like structures that covered both cell poles (Fig. 1b). The nature and function of these structures remain unknown; remarkably, they were not observed in cells grown in liquid cultures. Regardless of the growth conditions used, a well-developed system of intracytoplasmic membranes (ICM) typical of Methylocapsa acidiphila $\mathrm{B}^{\mathrm{T}}$ and other obligate methanotrophs was absent from cells of strains BW863 ${ }^{\mathrm{T}}$ and BW872. However, more precise examination of cross-sections (Fig. 1c) revealed that a few loosely arranged, rudimentary ICM were visible in some cells. Similar to members of the genus Methylocella, intracellular granules of poly- $\beta$-hydroxybutyrate were formed at each cell pole in strains BW863 ${ }^{\mathrm{T}}$ and BW872 (Fig. 1d).

Despite their close phylogenetic relationship to the methanotrophic bacterium Methylocapsa acidiphila $\mathrm{B}^{\mathrm{T}}$, the novel isolates were unable to grow on methane. All attempts to amplify a $p m o A$ gene fragment (encoding the
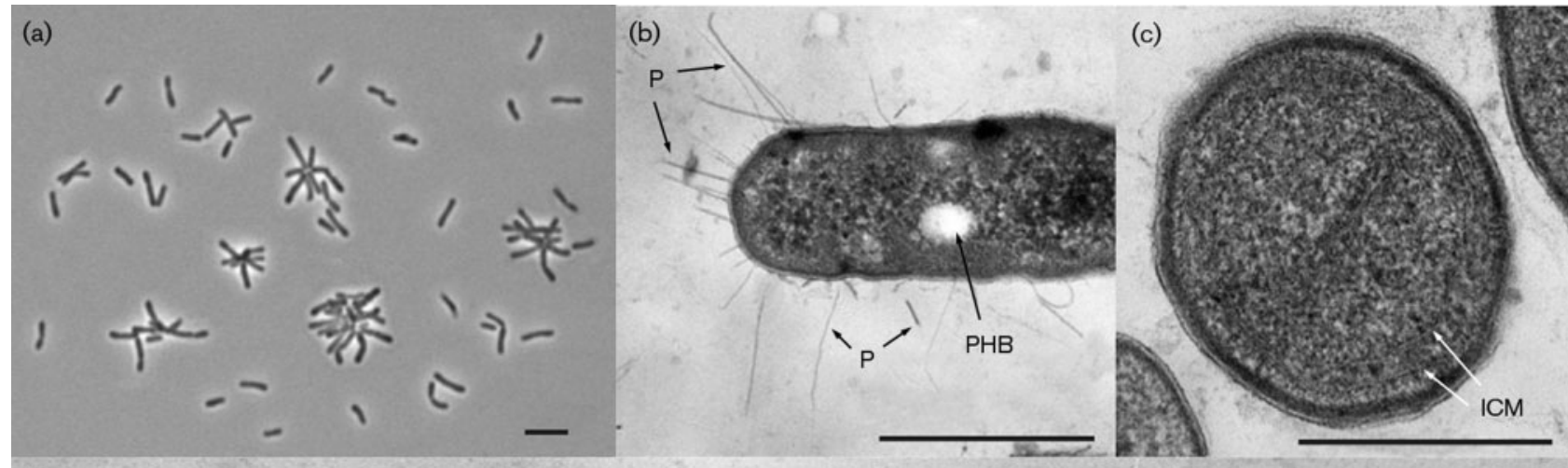

(d)

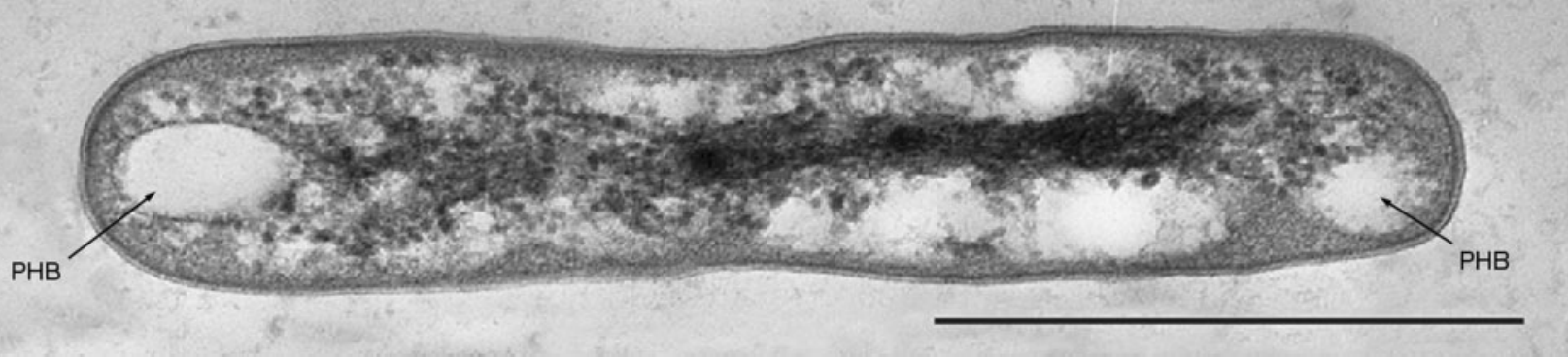

Fig. 1. (a) Phase-contrast micrograph of cells of strain $B W 863^{\top}$ grown in liquid mineral medium with methanol for 10 days. (bd) Electron micrographs of ultrathin sections of cells of strain BW863 ${ }^{\top}$ grown on solid mineral medium with methanol. PHB, Poly- $\beta$-hydroxybutyrate; $\mathrm{P}$, pilus-like structures; ICM, intracytoplasmic membranes. Bars, $5 \mu \mathrm{m}(\mathrm{a})$ and $0.5 \mu \mathrm{m}(\mathrm{b}-\mathrm{d})$. 
large subunit of the particulate methane monooxygenase) from DNA of strains BW863 ${ }^{\mathrm{T}}$ and BW872 using any of the primer sets A189/A682 (Holmes et al., 1995), A189/ Mb661r (Costello \& Lidstrom, 1999), A189/Mcap630r and A189/Forest675r (Kolb et al., 2003) for this gene were unsuccessful.

The major carbon and energy source for strains BW863 ${ }^{\mathrm{T}}$ and BW872 was methanol. It was utilized over a wide range of concentrations $(0.01-2 \%)$, with an optimum between 0.5 and $1 \%(\mathrm{v} / \mathrm{v})$. None of the other $\mathrm{C}_{1}$ compounds tested supported growth of these strains. In addition to methanol, the novel isolates were able to utilize ethanol, malate and pyruvate, but they did not grow on a range of sugars or other multicarbon compounds tested. Thus, strains BW863 ${ }^{\mathrm{T}}$ and BW872 should be regarded as restricted facultatively methylotrophic bacteria. Both isolates had an absolute requirement for the presence of growth factors in the cultivation medium (20-50 mg yeast extract $\left.~^{-1}\right)$. They utilized ammonium salts, nitrates and yeast extract as nitrogen sources. Strains BW863 ${ }^{\mathrm{T}}$ and BW872 were capable of slow growth in liquid nitrogen-free medium under microaerobic conditions (1.0-2.0\% $\mathrm{O}_{2}$ in flask headspace). The sequences of nifH gene fragments from these methylotrophs displayed highest similarity (86-88\%) to the corresponding gene fragments from acidophilic methanotrophs of the genus Methylocella and members of the genus Bradyrhizobium.

The isolates were obligately acidophilic and grew in the $\mathrm{pH}$ range 3.1-6.5, with an optimum at $\mathrm{pH} 4.5-5.0$ (Supplementary Fig. S2). The temperature range for growth was $4-30{ }^{\circ} \mathrm{C}$ (optimum at $20-24{ }^{\circ} \mathrm{C}$ ). No growth occurred at $37{ }^{\circ} \mathrm{C}$. Growth of strains BW863 ${ }^{\mathrm{T}}$ and BW872 was inhibited in the presence of $\mathrm{NaCl}$ in the medium at concentrations above $0.7 \%(\mathrm{w} / \mathrm{v})$.

Phospholipid fatty acid (PLFA) profiles of the novel methylotrophic isolates contained unusually large amounts of 11-cis-octadecenoic fatty acid $\left(\mathrm{C}_{18: 1} \omega 7 \mathrm{c}\right)$, which comprised $87-92 \%$ of the total PLFAs (Table 1), and were remarkably similar to the profiles described for representatives of the genus Methylobacterium (Kato et al., 2005, 2008). The latter, however, contain larger amounts of $C_{18: 0}$ and do not possess $\mathrm{C}_{19: 0}$ cyclo, which is one of the characteristic PLFAs in strains BW863 ${ }^{\mathrm{T}}$ and BW872. The predominance of $\mathrm{C}_{18: 1} \omega 7 \mathrm{c}$ in the PLFA profiles is also a feature specific to acidophilic methanotrophs of the genera

Table 1. PLFA compositions of strains $B W 863^{\top}$ and BW872 in comparison with phylogenetically related acidophilic methanotrophs

Values are percentages of total PLFAs; components representing $<0.1 \%$ of the total are not included. Major PLFAs are shown in bold. Data for reference species were taken from Dedysh et al. (2002) (Methylocapsa acidiphila) and from Dedysh et al. (2000, 2004a) and Dunfield et al. (2003) (Methylocella species).

\begin{tabular}{|c|c|c|c|c|}
\hline Fatty acid & BW863 $^{\mathrm{T}}$ & BW872 & Methylocapsa acidiphila & Methylocella \\
\hline $\mathrm{C}_{14: 0}$ & 0 & 0 & 0 & $0-4.1$ \\
\hline iso- $\mathrm{C}_{15: 0}$ & 0 & 0 & 0.1 & $0.2-1.2$ \\
\hline $\mathrm{C}_{15: 0}$ & 0 & 0 & 0 & $0-0.1$ \\
\hline $\mathrm{C}_{16: 0}$ & 1.80 & 1.96 & 7.3 & $3.0-7.7$ \\
\hline 10-Methyl $C_{16: 0}$ & 0 & 0.37 & 0 & 0 \\
\hline $\mathrm{C}_{16: 1} \omega 7 c$ & 0.33 & 0.36 & 4.7 & $4.7-11.3$ \\
\hline $\mathrm{C}_{16: 1} \omega 7 t$ & 0 & 0 & 0 & $0-5.8$ \\
\hline iso- $\mathrm{C}_{17: 1} \omega 9 c$ & 0 & 0 & 0 & $0-0.3$ \\
\hline anteiso- $\mathrm{C}_{17: 0}$ & 0 & 0.21 & 0 & $0-0.3$ \\
\hline $\mathrm{C}_{17: 0}$ & 0.53 & 0.64 & 0.1 & $0-0.1$ \\
\hline iso- $\mathrm{C}_{17: 0}$ & 0.23 & 0 & 0.6 & $0-2.5$ \\
\hline br- $C_{17: 0}$ & 0.23 & 0.25 & 0 & 0 \\
\hline $\mathrm{C}_{17: 0}$ cyclo & 0 & 0.18 & 0 & $0-6.5$ \\
\hline $\mathrm{C}_{17: 1} \omega 8 c$ & 0 & 0 & 0 & $0-0.3$ \\
\hline $\mathrm{C}_{17: 1} \omega 7 c$ & 0.16 & 0.19 & 1.0 & 0 \\
\hline iso- $\mathrm{C}_{18: 0}$ & 0 & 0 & 0 & $0-0.5$ \\
\hline $\mathrm{C}_{18: 0}$ & 0.83 & 0.91 & 7.6 & $0.4-1.2$ \\
\hline $\mathrm{C}_{18: 1} \omega 9 c$ & 0 & 0.41 & 0 & 0 \\
\hline $\mathrm{C}_{18: 1} \omega 8 c$ & 0 & 0 & 0 & 0 \\
\hline $\mathrm{C}_{18: 1} \omega 7 c$ & 87.07 & 92.76 & 78.3 & $59.2-82.2$ \\
\hline $\mathrm{C}_{18: 1} \omega 5 c$ & 0 & 0 & 0 & $0-0.1$ \\
\hline $\mathrm{C}_{19: 0}$ cyclo & 2.57 & 1.39 & 0 & 0 \\
\hline $\mathrm{C}_{19: 1} \omega 8 c$ cyclo & 0 & 0 & 0 & 0-13.6 \\
\hline $\mathrm{C}_{19: 0}$ & 0 & 0 & 0 & $0-0.6$ \\
\hline $\mathrm{C}_{20: 0}$ & 0.11 & 0.13 & 0 & 0 \\
\hline
\end{tabular}


Methylocapsa and Methylocella (Dedysh et al., 2000, 2002, 2004a; Dunfield et al., 2003). However, the PLFA profiles of acidophilic methanotrophs also include other major components, such as $\mathrm{C}_{16: 0}, \mathrm{C}_{16: 1} \omega 7 c, \mathrm{C}_{18: 0}$ and $\mathrm{C}_{19: 1} \omega 8 c$ cyclo, while these PLFAs were either present in minor amounts or absent from cells of strains $B W 863^{\mathrm{T}}$ and BW872. Polar lipid profiles of strains BW863 ${ }^{\mathrm{T}}$ and BW872 were nearly identical and consisted of phosphatidylethanolamine (about 35\%), phosphatidylcholine (30\%) and phosphatidylglycerol (30\%). By contrast, the major phospholipids in Methylocapsa acidiphila and Methylocella species were phosphatidylglycerol and phosphatidylmethylethanolamine, respectively (Dedysh et al., 2000; Fang et al., 2000).

In order to establish the routes of primary $\mathrm{C}_{1}$ metabolism employed by the novel methylotrophs, enzyme activities were determined in extracts of cells grown on methanol. Since the two strains displayed nearly identical enzyme profiles, results are shown only for strain $B W 863^{\mathrm{T}}$ (Table 2). This bacterium possessed a pyrroloquinoline quinone-containing methanol dehydrogenase, which required alkaline $\mathrm{pH}$ and $\mathrm{NH}_{4}^{+}$ions for activity in vitro with phenazine methosulfate (PMS) as an artificial electron acceptor. Two formaldehyde-oxidizing enzymes were present, NAD-dependent formaldehyde dehydrogenase and the PMS-linked form. Also, the NAD-dependent and PMS-linked forms of formate dehydrogenase were detected. Thus, strain $B W 863^{\mathrm{T}}$ appears to possess the complete set of enzymes involved in methanol oxidation to $\mathrm{CO}_{2}$ through formaldehyde and formate that provides metabolic energy for methylotrophic growth. The presence of the two enzymes unique to the ribulose bisphosphate $(\mathrm{RuBP})$ pathway for $\mathrm{C}_{1}$ assimilation, phosphoribulokinase

Table 2. Enzyme activities in cell extracts of strain BW863 ${ }^{\top}$ grown on methanol

Data are enzyme activities expressed as $\mathrm{nmol} \mathrm{min}^{-1}(\mathrm{mg} \text { protein })^{-1}$.

\begin{tabular}{|lcr|}
\hline Enzyme & Cofactor(s) & Activity \\
\hline Methanol dehydrogenase & $\mathrm{PMS}$ & 220 \\
Formaldehyde dehydrogenase & $\mathrm{PMS}^{+}$ & 30 \\
& $\mathrm{NAD}^{+}$ & 10 \\
Formate dehydrogenase & $\mathrm{PMS}^{+}$ & 80 \\
& $\mathrm{NAD}^{+}$ & 20 \\
3-Hexulosephosphate synthase & & 0 \\
Hydroxypyruvate reductase & $\mathrm{NADH}$ & 268 \\
& $\mathrm{NADPH}$ & 67 \\
Serine-glyoxylate aminotransferase & $\mathrm{NADH}$ & 0 \\
& $\mathrm{NADPH}$ & 0 \\
Malyl-CoA synthetase/CoA lyase & $\mathrm{ATP}, \mathrm{CoA}$ & 0 \\
Glycerate kinase & $\mathrm{ATP}$ & 0 \\
Phosphoribulokinase & $\mathrm{ATP}$ & 51 \\
Ribulose-1,5-bisphosphate carboxylase & & 82 \\
Isocitrate dehydrogenase & $\mathrm{NAD}$ & 2 \\
& $\mathrm{NADP}$ & 40 \\
\hline
\end{tabular}

and $\mathrm{RuBisCO}$, suggested that the carbon derived from the oxidation of methanol was assimilated at the level of $\mathrm{CO}_{2}$ via the RuBP pathway. Detection and partial sequence analysis of $c b b L$, the gene encoding form-I RuBisCO, provided genotypic evidence for autotrophic metabolism in strains BW863 ${ }^{\mathrm{T}}$ and BW872. The two strains displayed identical $c b b L$ gene sequences. The highest nucleotide sequence identity to the $c b b L$ gene fragments of the novel methylotrophic isolates was shown by strains of Beijerinckia mobilis (86\%), Telmatospirillum sibiriense $(86 \%)$ and Methylocapsa acidiphila (85\%). Neither the serine pathway nor the ribulose monophosphate pathway of $\mathrm{C}_{1}$ assimilation was operative as a result of the absence of the appropriate specific enzymes, i.e. serine-glyoxylate aminotransferase, malyl-CoA-lyase, glycerate kinase and hexulosephosphate synthase. Isocitrate dehydrogenase was active with NADP.

A phylogenetic tree constructed on the basis of $16 \mathrm{~S}$ rRNA gene sequences (Fig. 2) indicated that strains $B W 863^{\mathrm{T}}$ and BW872 belong to the family Beijerinckiaceae of the class Alphaproteobacteria. The closest taxonomically described phylogenetic neighbour of these isolates was the acidophilic, obligately methanotrophic bacterium Methylocapsa acidiphila $\mathrm{B}^{\mathrm{T}}{ }^{\mathrm{T}}$ (3-3.5\% sequence difference). However, $16 \mathrm{~S}$ rRNA gene sequences from the two novel strains and Methylocapsa acidiphila $\mathrm{B}^{\mathrm{T}}$ did not group together if environmental sequences OP1, OP3 and OP8, which were retrieved by means of the SIP technique from different acidic soils amended with ${ }^{13} \mathrm{C}$-methanol (Radajewski et al., 2000, 2002), were included in comparative sequence analysis (Supplementary Fig. S3). In this case, strains BW863 ${ }^{\mathrm{T}}$ and BW872 grouped together with these environmental sequences, and the bootstrap value for the common branch point of this cluster was quite high $(90 \%)$. Other phylogenetically close and taxonomically characterized organisms were acidophilic, facultatively methanotrophic bacteria of the genus Methylocella (4.3-4.4\% sequence difference) and acidophilic heterotrophic bacteria of the genus Beijerinckia (4.3-4.4\% sequence difference).

Comparative sequence analysis of $m x a F$, the gene encoding the large subunit of methanol dehydrogenase, placed the deduced MxaF sequences of the two novel strains in a cluster that is distinct from all previously described $\mathrm{MxaF}$ sequences of cultivated methylotrophs (Fig. 3). The identity between the deduced MxaF sequences of our isolates and those from known alpha-, beta- and gammaproteobacterial methylotrophic bacteria was 69-75, 61-63 and $64-67 \%$, respectively. Interestingly, the deduced $\mathrm{MxaF}$ sequences of strains BW863 ${ }^{\mathrm{T}}$ and BW872 were closely affiliated (95.6-97.5\%) with the inferred peptide sequences of $m x a F$ clones retrieved by means of the SIP technique from different acidic soils amended with ${ }^{13} \mathrm{C}$-methanol (Radajewski et al., 2000; 2002). Thus, our novel isolates are the first representatives of this previously uncultivated group of methylotrophic bacteria, which were earlier detected in acidic terrestrial environments by means of molecular approaches. 


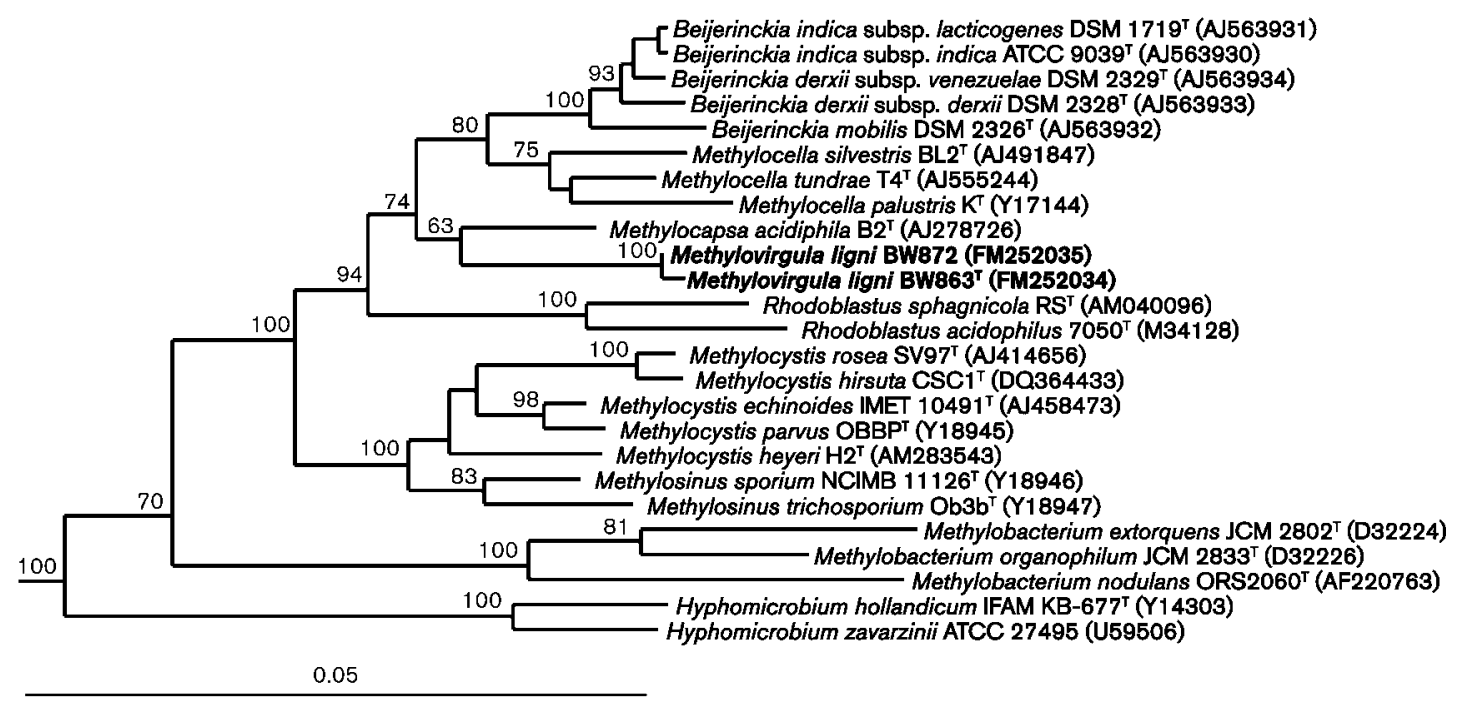

Fig. 2. $16 \mathrm{~S}$ rRNA gene sequence-based neighbour-joining tree showing the phylogenetic positions of strains $B W 863^{\top}$ and BW872 in relation to other members of the family Beijerinckiaceae and some other representatives of the Alphaproteobacteria. The sequences of the type I methanotrophs Methylomicrobium album ACM $3314^{\top}$ (GenBank accession no. X72777), Methylobacter luteus NCIMB $11914^{\top}$ (AF304195), Methylomonas methanica S1 ${ }^{\top}$ (AF304196) and Methylococcus capsulatus Texas (AJ563935) were used as an outgroup (not shown). Bootstrap values (percentages of 1000 data resamplings) $>50 \%$ are shown. Bar, 0.05 substitutions per nucleotide position.

In summary, our novel isolates from decaying wood possessed a number of characteristics that clearly distinguished them from other methylotrophic members of the family Beijerinckiaceae (Table 3). Cell morphology, the absence of a slimy capsule and the requirement for growth factors made strains $\mathrm{BW} 863^{\mathrm{T}}$ and BW872 different from all other currently described members of this family. The inability to grow on methane, their obligate acidophily and the use of the RuBP pathway for $\mathrm{C}_{1}$ assimilation distinguished them from members of the genera Methylocapsa and Methylocella. The inability to utilize sugars distinguished the isolates from members of the genus Beijerinckia. Therefore, we propose a novel genus and a novel species, Methylovirgula ligni gen. nov., sp. nov., to accommodate strains $B W 863^{\mathrm{T}}$ and BW872.

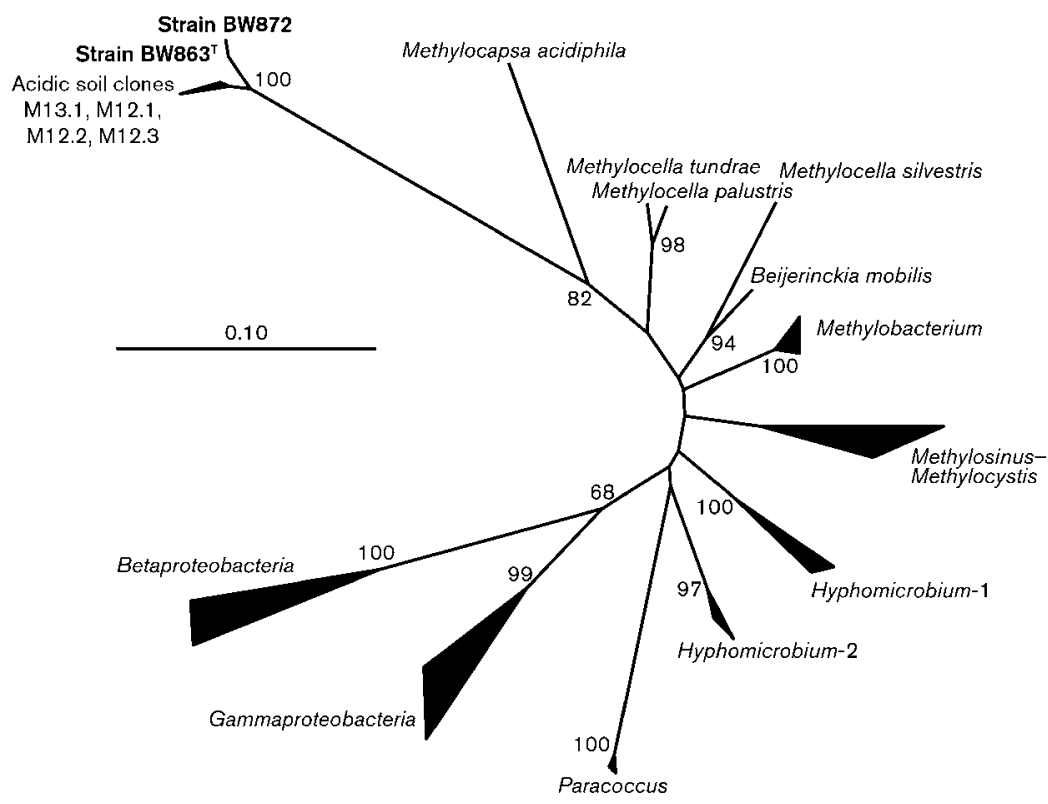

Fig. 3. Unrooted neighbour-joining tree (PAM correction) constructed based on 170 deduced amino acid sites of partial $m \times a F$ gene sequences, showing the positions of strains $\mathrm{BW} 83^{\top}$ and $\mathrm{BW} 872$ relative to environmental sequences retrieved in SIP-based studies from acidic soils and other proteobacterial methylotrophs. Bootstrap values (1000 data resamplings) $>60 \%$ are shown. Bar, 0.1 substitutions per nucleotide position. 
Table 3. Major characteristics that distinguish strains $B W 863^{\top}$ and $B W 872$ (Methylovirgula ligni gen. nov., sp. nov.) from other methylotrophic members of the family Beijerinckiaceae

Data for reference species were taken from Dedysh et al. (2002) (Methylocapsa acidiphila), from Dedysh et al. (2000, 2004a, 2005b) and Dunfield et al. (2003) (Methylocella) and from Becking (2006) and Dedysh et al. (2005a) (Beijerinckia mobilis). v, Variable (present in Methylocella palustris and Methylocella silvestris and absent in Methylocella tundrae); ND, not determined/no data available.

\begin{tabular}{|c|c|c|c|c|}
\hline Characteristic & Methylovirgula ligni & Methylocapsa acidiphila & Methylocella & Beijerinckia mobilis \\
\hline Cell morphology & Straight or curved rods & Curved coccoids & $\begin{array}{l}\text { Bipolar straight or } \\
\text { curved rods }\end{array}$ & $\begin{array}{l}\text { Straight, curved or } \\
\text { pear-shaped rods }\end{array}$ \\
\hline Cell size $(\mu \mathrm{m})$ & $0.3-0.65 \times 1.2-2.5$ & $0.7-1.0 \times 0.8-1.2$ & $0.6-1.0 \times 1.0-2.5$ & $0.6-1.0 \times 1.6-3.0$ \\
\hline Rosette formation & + & - & - & - \\
\hline Capsule & - & + & $\mathrm{v}$ & + \\
\hline Resting cells & None & Cysts & None & None \\
\hline Type of metabolism & Facultative methylotrophy & Obligate methanotrophy & Facultative methanotrophy & Facultative methylotrophy \\
\hline \multicolumn{5}{|l|}{ Growth on: } \\
\hline Methane & - & + & + & - \\
\hline Methanol (\% v/v) & Good (0.01-2) & Poor $(<0.05)$ & Good (0.01-5) & Good (0.01-3) \\
\hline $\begin{array}{l}\text { Multicarbon compounds } \\
\text { utilized }\end{array}$ & Pyruvate, malate, ethanol & - & $\begin{array}{c}\text { Acetate, pyruvate, succinate, } \\
\text { malate, ethanol }\end{array}$ & $\begin{array}{l}\text { Most sugars, some } \\
\text { organic acids, alcohols, } \\
\text { aromatic compounds }\end{array}$ \\
\hline $\mathrm{C}_{1}$-utilization pathway & RuBP & Serine & Serine & RuBP \\
\hline Growth factor requirement & + & - & - & - \\
\hline \multicolumn{5}{|l|}{ Growth at/in: } \\
\hline $35{ }^{\circ} \mathrm{C}$ & - & - & - & + \\
\hline pH 7.0 & - & + & + & + \\
\hline $\mathrm{pH} 3.5$ & + & - & - & + \\
\hline $0.5 \% \mathrm{NaCl}$ & + & - & - & + \\
\hline Major phospholipid(s)* & PE, PC, PG & PG & PME & ND \\
\hline
\end{tabular}

${ }^{\star}$ PC, Phosphatidylcholine; PE, phosphatidylethanolamine; PG, phosphatidylglycerol; PME, phosphatidylmethylethanolamine.

\section{Description of Methylovirgula gen. nov.}

Methylovirgula (Me.thy.lo.vir'gu.la. N.Gr. n. methyl the methyl group from Gr. n. methu wine and Gr. n. hulê wood; L. fem. n. virgula a little rod; N.L. fem. n. Methylovirgula methyl-using rod-shaped cell).

Gram-negative, aerobic, colourless, non-motile, thin rods that occur singly or are arranged in rosettes and misshapen cell clusters. Reproduce by binary fission. Colonies are small, circular, smooth and convex. The colony colour varies from white to cream. Produce poly$\beta$-hydroxybutyrate. Obligately acidophilic and mesophilic. Prefer dilute media of low salt content. Restricted facultative methylotrophs. Assimilate methanol-derived carbon via the RuBP pathway. Capable of atmospheric nitrogen fixation. The major phospholipid fatty acid is $\mathrm{C}_{18: 1} \omega 7 c$ and the major phospholipids are phosphatidylethanolamine, phosphatidylcholine and phosphatidylglycerols. The major quinone is $\mathrm{Q}-10$. The $\mathrm{G}+\mathrm{C}$ content of the DNA varies between 61.8 and $62.8 \mathrm{~mol} \%$. Member of the class Alphaproteobacteria, family Beijerinckiaceae. The type and only species is Methylovirgula ligni. Strains have been isolated from acidic soils and decaying wood.

\section{Description of Methylovirgula ligni sp. nov.}

Methylovirgula ligni (lig' ni. L. gen. n. ligni of wood, referring to the isolation of known strains from wood material).

Description as for the genus plus the following traits. Cells are $0.3-0.65 \mu \mathrm{m}$ wide and $1.2-2.5 \mu \mathrm{m}$ long. Resting cell forms are absent. Carbon sources include methanol, ethanol, pyruvate and malate. Grows optimally at methanol concentrations of $0.5-1 \%$. Nitrogen sources used (at $0.05 \%, \mathrm{w} / \mathrm{v}$ ) include ammonia, nitrate and yeast extract. Growth factors are required. Capable of growth at $\mathrm{pH} 3.1-6.5$ (optimum $\mathrm{pH} 4.5-5.0$ ) and at $4-30{ }^{\circ} \mathrm{C}$ (optimum $20-24{ }^{\circ} \mathrm{C}$ ). $\mathrm{NaCl}$ inhibits growth at concentrations above $0.7 \%(\mathrm{w} / \mathrm{v})$.

The type strain is strain $\mathrm{BW}^{\mathrm{T}} \mathrm{3}^{\mathrm{T}}$ (=DSM $19998^{\mathrm{T}}$ $=$ NCIMB $14408^{\mathrm{T}}$ ), which was isolated from decaying beechwood blocks incubated on an acidic forest soil from the central part of the Netherlands.

\section{Acknowledgements}

This research was supported by the Programs 'Molecular and Cell Biology' and 'Biodiversity' of the Russian Academy of Sciences and by the RosNauka project no. 02.512.12.0027. The authors want to thank 
Kees Hordijk for technical assistance in PLFA analyses and Elena N. Kaparullina for the phospholipid analyses.

\section{References}

Ander, P. \& Eriksson, K.-E. (1984). Methanol formation during lignin degradation by Phanerochaete chrysosporium. Appl Microbiol Biotechnol 21, 96-102.

Becking, J. H. (2006). The genus Beijerinckia. In The Prokaryotes, 3rd edn, vol. 5, pp. 151-162. Edited by M. Dworkin, S. Falkow, E. Rosenberg, K. H. Schleifer \& E. Stackebrandt. New York: Springer.

Collins, M. D. (1985). Analysis of isoprenoid quinones. Methods Microbiol 18, 329-366.

Costello, A. M. \& Lidstrom, M. E. (1999). Molecular characterization of functional and phylogenetic genes from natural populations of methanotrophs in lake sediments. Appl Environ Microbiol 65, 5066-5074.

Dedysh, S. N., Liesack, W., Khmelenina, V. N., Suzina, N. E., Trotsenko, Y. A., Semrau, J. D., Bares, A. M., Panikov, N. S. \& Tiedje, J. M. (2000). Methylocella palustris gen. nov., sp. nov., a new methaneoxidizing acidophilic bacterium from peat bogs, representing a novel subtype of serine-pathway methanotrophs. Int J Syst Evol Microbiol 50, 955-969.

Dedysh, S. N., Khmelenina, V. N., Suzina, N. E., Trotsenko, Y. A., Semrau, J. D., Liesack, W. \& Tiedje, J. M. (2002). Methylocapsa acidiphila gen. nov., sp. nov., a novel methane-oxidizing and dinitrogen-fixing acidophilic bacterium from Sphagnum bog. Int J Syst Evol Microbiol 52, 251-261.

Dedysh, S. N., Berestovskaya, Y. Y., Vasylieva, L. V., Belova, S. E., Khmelenina, V. N., Suzina, N. E., Trotsenko, Y. A., Liesack, W. \& Zavarzin, G. A. (2004a). Methylocella tundrae sp. nov., a novel methanotrophic bacterium from acidic tundra peatlands. Int J Syst Evol Microbiol 54, 151-156.

Dedysh, S. N., Ricke, P. \& Liesack, W. (2004b). NifH and NifD phylogenies: a molecular basis for understanding nitrogen fixation capabilities of methanotrophic bacteria. Microbiology 150, 1301-1313.

Dedysh, S. N., Smirnova, K. V., Chmelenina, V. N., Suzina, N. E., Liesack, W. \& Trotsenko, Y. A. (2005a). Methylotrophic autotrophy in Beijerinckia mobilis. J Bacteriol 187, 3884-3888.

Dedysh, S. N., Knief, C. \& Dunfield, P. (2005b). Methylocella species are facultatively methanotrophic. J Bacteriol 187, 4665-4670.

Dedysh, S. N., Belova, S. E., Bodelier, P. L. E., Smirnova, K. V., Khmelenina, V. N., Chidthaisong, A., Trotsenko, Y. A., Liesack, W. \& Dunfield, P. F. (2007). Methylocystis heyeri sp. nov., a novel type II methanotrophic bacterium possessing 'signature' fatty acids of type I methanotrophs. Int J Syst Evol Microbiol 57, 472-479.

Dunfield, P. F., Khmelenina, V. N., Suzina, N. E., Trotsenko, Y. A. \& Dedysh, S. N. (2003). Methylocella silvestris sp. nov., a novel methanotrophic bacterium isolated from an acidic forest cambisol. Int J Syst Evol Microbiol 53, 1231-1239.

Fang, J., Barcelona, M. J. \& Semrau, J. D. (2000). Characterization of methanotrophic bacteria on the basis of intact phospholipid profiles. FEMS Microbiol Lett 189, 67-72.

Folman, L. B., Klein Gunnewiek, P. J. A., Boddy, L. \& de Boer, W. (2008). Impact of white-rot fungi on numbers and community composition of bacteria colonizing beech wood from forest soil. FEMS Microbiol Ecol 63, 181-191.
Holmes, A. J., Costello, A., Lidstrom, M. E. \& Murrell, J. C. (1995). Evidence that particulate methane monooxygenase and ammonium monooxygenase may be evolutionarily related. FEMS Microbiol Lett 132, 203-208.

Kates, M. (1972). Techniques of Lipidology. New York: Elsevier.

Kato, Y., Asahara, M., Arai, D., Goto, K. \& Yokota, A. (2005). Reclassification of Methylobacterium chloromethanicum and Methylobacterium dichloromethanicum as later subjective synonyms of Methylobacterium extorquens and of Methylobacterium lusitanum as a later subjective synonym of Methylobacterium rhodesianum. J Gen Appl Microbiol 51, 287-299.

Kato, Y., Asahara, M., Goto, K., Kasai, H. \& Yokota, A. (2008). Methylobacterium persicinum sp. nov., Methylobacterium komagatae sp. nov., Methylobacterium brachiatum sp. nov., Methylobacterium tardum sp. nov. and Methylobacterium gregans sp. nov., isolated from freshwater. Int J Syst Evol Microbiol 58, 1134-1141.

Kolb, S., Knief, C., Stubner, S. \& Conrad, R. (2003). Quantitative detection of methanotrophs in soil by novel pmoA-targeted real-time PCR assays. Appl Environ Microbiol 69, 2423-2429.

Lidstrom, M. E. (2006). Aerobic methylotrophic prokaryotes. In The Prokaryotes, 3rd edn, vol. 2, pp. 618-634. Edited by M. Dworkin, S. Falkow, E. Rosenberg, K. H. Schleifer \& E. Stackebrandt. New York: Springer.

Ludwig, W., Strunk, O., Westram, R., Richter, L., Meier, H., Yadhukumar, Buchner, A., Lai, T., Steppi, S., Jobb, G. \& other authors (2004). ARB: a software environment for sequence data. Nucleic Acids Res 32, 1363-1371.

McDonald, I. R. \& Murrell, J. C. (1997). The methanol dehydrogenase structural gene $m x a F$ and its use as a functional gene probe for methanotrophs and methylotrophs. Appl Environ Microbiol 63, 32183224.

Owen, R. J., Lapage, S. P. \& Hill, L. R. (1969). Determination of base composition from melting profiles in dilute buffers. Biopolymers 7 , 503-516.

Radajewski, S., Ineson, P., Parekh, N. R. \& Murrell, J. C. (2000). Stable-isotope probing as a tool in microbial ecology. Nature 403, 646-649.

Radajewski, S., Webster, G., Reay, D. S., Morris, S. A., Ineson, P., Nedwell, D. B., Prosser, J. I. \& Murrell, J. C. (2002). Identification of active methylotroph populations in an acidic forest soil by stableisotope probing. Microbiology 148, 2331-2342.

Reynolds, E. S. (1963). The use of lead citrate at high $\mathrm{pH}$ as an electron opaque stain in electron microscopy. J Cell Biol 17, 208-212.

Spiridonova, E. M., Berg, I. A., Kolganova, T. V., Ivanovsky, R. N., Kuznetsov, B. B. \& Tourova, T. P. (2004). An oligonucleotide primer system for amplification of the ribulose-1,5-bisphosphate carboxylase/oxygenase genes of bacteria of various taxonomic groups. Microbiology (English translation of Mikrobiologiia) 73, 316-325.

Warneke, C., Karl, T., Judmaier, H., Hansel, A., Jordan, A., Lindinger, W. \& Crutzen, P. J. (1999). Acetone, methanol, and other partially oxidized volatile organic emissions from dead plant matter by abiological processes: significance for atmospheric chemistry. J Geophys Res 13, 9-18.

Weisburg, W. G., Barns, S. M., Pelletier, D. A. \& Lane, D. J. (1991). 16 S ribosomal DNA amplification for phylogenetic study. J Bacteriol 173, 697-703. 